\title{
A Proposed Credit Risk Assessment for People at the Bottom of the Social Pyramid in Cali, Colombia
}

\author{
Juan David Rivera Acevedo ${ }^{1} \&$ Lina Martínez ${ }^{2}$ \\ ${ }^{1}$ Lecturer Brandt School of Public Policy. PhD Candidate Center for Empirical Research in Economics and Behavioral \\ Sciences (CEREB) University of Erfurt, Germanys \\ ${ }^{2}$ Professor Universidad Icesi. Director Observatory of Public Policies (POLIS). Cali, Colombia \\ Correspondence: Juan David Rivera Acevedo, Lecturer Brandt School of Public Policy. PhD Candidate Center for \\ Empirical Research in Economics and Behavioral Sciences (CEREB) University of Erfurt, Germany. Nordhäuser Str. \\ 6399089 Erfurt. E-mail: juan_david.rivera_acevedo@uni-erfurt.de.
}

Received: April 10, 2018 Accepted: April 26, 2018 Online Published: May 30, 2018

doi:10.5539/res.v10n3p41 URL: https://doi.org/10.5539/res.v10n3p41

\begin{abstract}
The informal economy accounts for half of the economic activity in Colombia. Street vending is a major part of the informal sector. In the context of a rapid urbanization due to internal conflicts, low skilled workers find a last resort for income generation as street vendors. Even though studies have revealed that street vendors can have high profits, they usually remain poor. A primary reason is their continuous indebtedness outside the regulated financial market. This paper proposes a comprehensive questionnaire survey on the socioeconomic profile of street vendors. This tool can be used to assess the individual credit risk and incentivize the financial inclusion of the poor. It can also be used for evaluation processes by the government or impact investors.
\end{abstract}

Keywords: Colombia, Credit Risk, Impact Investing, Informal Economy, Microfinance

\section{Introduction}

The informal economy in Colombia, like in many other countries in South America, accounts for about $50 \%$ of the economic activity (ILO, 2014). Within the informal sector, street vending constitutes an important share. As an economic sector, it is dynamic and provides goods and services to a large population. There is not enough accurate data to establish the number of street vendors in Colombia or their living conditions, but the information available shows that street vendors usually belong to the poor population and that low-skilled jobs are their last resort of income generation (Donovan, 2008; Martínez et al., 2017).

Due to the many intersections with poverty reduction, the low-skilled labor market and urban planning, street vending constitutes a relevant topic on the national and local policy agenda and is therefore an important area of research. Motivated by the significant role that street vending plays in the Global South, the authors have undertaken several studies to understand the living conditions and the socioeconomic dimension of this occupation in Cali, Colombia (Martínez \& Short, 2016; Martínez et al., 2017; Martínez \& Estrada, 2017). It was found that street vendors report a higher income than the average citizen, but they are unable to capitalize on their earnings and escape poverty. The reason is a vicious circle of indebtedness and a high dependency on loan sharks (Martinez \& Rivera-Acevedo, forthcoming). Nevertheless, street vendors show the financial capacity to pay back their debts. The assumption is that they would profit from access to credits from a bank or microfinance institution with lower interest rates, or other legal financial instruments.

Until now, the policies that different local governments in Colombia have implemented to cope with street vending, such as relocating the vendors, have not worked. Intervention programs that consider the needs of street vendors are rare and vary from city to city (Martínez \& Short, 2016). Social programs targeting informal workers, and street vendors in particular, should also focus on strategies for financial inclusion. This aspect has not yet been taken into account by the government. The goal of this paper is to contribute with a tool that helps craft targeted interventions aimed at increasing the financial inclusion of informal workers.

This study presents a survey with 62 questions on demographic aspects, employment and health care, household characteristics, income and expenses, access to the banking system and credit history. All the questions have been used and tested before by either the government, regulated financial institutions or the authors in previous studies, but are arranged in a new constellation for the purpose of this study. The results of the survey can be used to create a profile of the 
poor that discloses their financial status and reveals under which conditions they are creditworthy. This instrument of individual credit risk assessment can reduce information asymmetries and help include the poor population into the formal financial market.

The paper is divided into four sections. The first section gives an overview of the urbanization process in Colombia, the role of the informal economy and the limited access of poor people to different legal financial institutions (e.g. bank, MFI). It also gives an overview of different mechanisms of financial inclusion in Colombia. The second section presents the suggested questionnaire survey to profile the creditworthiness of poor population groups. Afterwards, policy recommendations and alternative financial instruments are discussed in the third section, and conclusions are drawn in the fourth section.

\section{The Informal Economy and Financial Access in Colombia}

Latin America experienced a rapid urbanization between 1925 and 1975, rising from $25 \%$ to $61.2 \%$ of the population living in cities (Cerrutti \& Bertoncello, 2003). Urbanization has contributed to reduce poverty and child mortality rates, and increase human development indicators such as educational attainment (Christiaensen \& Todo, 2014). Colombia, as one of the major countries in the region (48 million inhabitants), experienced the same transformation. Nowadays, about $75 \%$ of the population in Colombia lives in cities (DANE, 2015a). There are three populous cities in the country: Bogotá (7 million), Medellin (2.5 million) and Cali (2.4 million).

Cali is an economic hub in the Pacific region. It is located in the department of Valle del Cauca, which contributes to about 4.1 percent of total GDP in the country (Banco de la República, 2013). Most of its economic activity has derived from sugar cane production and other agricultural activities.

One of the major drives of population growth in Cali is rooted in the armed conflict. In 1990, the city had only about 1.7 million inhabitants, and the large population growth experienced in the last decades is partially due to the resettlement of displaced people (Poveda, 2011). These migration flows have aggravated inequality, increased poverty and restrained economic opportunities for poor people. It is estimated that about $25 \%$ of the city population lives in poverty (DANE, 2013).

The Colombian government stratifies neighborhoods and households according to access to public services. This stratification is a mechanism to classify households based on their living and socioeconomic conditions. The strata scale goes from one to six: one and two are classified as poor; three and four represent the middle class; five and six are classified as rich (DNP, 1997).

For most poor people (strata 1 and 2), an economic activity in the informal sector is the last resort to earn a living. In Colombia, the informal economy covers a wide range of activities, from garbage collectors to street vendors and owners of small companies (ILO-FORLAC, 2014). Given the heterogeneity of this sector and the lack of reliable data, it is difficult to assess the magnitude of the informal economy. However, official statistics report that about half of the population in Colombia earns a living with an informal occupation (DANE, 2015b). People who work in the informal sector are characterized by the lack of a sufficient skill set to find employment in the formal sector, unstable working conditions and vulnerability to economic slowdowns due to an insufficient social protection system (Gaspirini \& Tornarolli, 2007).

Another important characteristic of the informal sector is the exclusion from formal economic structures like banking (Chen, 2005, 2012). Informal workers do not have access to credit by regulated financial institutions given their lack of collateral and/or employment stability. Traditionally, banks grant large loans to clients with a low credit risk which allows a low transaction cost per dollar lent and a high probability of repayment. Lending to the poor is not attractive for traditional financial institutions because of the high administrative cost, lack of deposits and low revenues (Serrano-Cinca \& Gutierrez-Nieto, 2014). The exclusion from formal financial services pushes the poor towards informal credit markets, such as payday-loans or moneylenders, who charge predatory interest rates (Mallick, 2012). Despite certain limitations, the main resource of formal credit for people at the bottom of the pyramid are microfinance institutions (from now on MFIs) (Banerjee et al., 2015; Weiss \& Montgomery, 2005; Quinones \& Remenyi, 2014).

The literature offers a mixed picture regarding MFIs. On the one hand, some researchers claim that microcredits do not only increase income and consumption, but also have a positive impact on the quality of life of the borrowers (Swain, 2012). On the other hand, it is argued that high interest rates and unethical collection methods may compromise this positive effect of credit accessibility to the poor (Kar \& Swain, 2014). Contrary to traditional businesses, the strong social principles of some MFIs drive them to find "difficult" customers instead of focusing on their most profitable customers (Serrano-Cinca et al., 2015). It is important to point out that loans to the poor have repayment rates of 97\% (Ashta, 2009). However, in environments with large information asymmetry, borrowers tend to take multiple loans from different MFIs (also known as double-dipping) and combine them with loans from moneylenders which leads to inefficiencies and 
ultimately default (Guha \& Chowdhury, 2013; Mallick, 2012).

Microcredits have a high transaction cost which translates into high interest rates for the poor. The interest rates demanded by MFIs are the result of: losses due to loan impairment, profits (or re-investments for NGOs and non-for-profit MFIs), cost of capital and cost of screening, monitoring and enforcing small loans (Armendáriz \& Morduch, 2010; Kar \& Swain, 2014; Roberts, 2013). The administrative cost of microloans can go up to 40 percent of the loan size (Braverman \& Guasch, 1989). This creates a bias towards short-term production cycle investments, such as petty retail, where borrowers can follow tight repayment schedules soon after the loan is granted (Dalla Pellegrina, 2011). Furthermore, different borrowers face different transaction costs, but the lack of information blocks the opportunity to offer loans which are tailored to the needs of individual borrowers (Guha \& Chowdhury, 2013). In Colombia, the maximum interest rates demanded by MFIs are regulated by the government. At the time of this research, the cap for microcredits is $4.58 \%$ per month (Superintendencia Financiera de Colombia, 2017).

Moneylenders have the same kind of transaction costs as MFIs (screening, monitoring and enforcing small loans), but demand higher interest rates due to the illegal nature of moneylending (about $20 \%$ per month). However, they are more convenient than MFIs in terms of accessibility and cash-flow. For example, a worker enforcing a loan for an illegal moneylender requires a higher wage than an employee in an MFI because wages include the opportunity cost of potentially being incarcerated.

Apart from MFIs, some cities Colombia are exploring different mechanisms sponsored and/or regulated by the government that provide credit access for the poor. One mechanism is through utility companies (operated by the government or private investors). Two examples stand out. The first one is called "Brilla" and covers several regions in the country. This program is operated by a private gas company. After revising the clients' payment history, the company offers clients with good credit records the opportunity to use a line of credit to buy durable assets such as appliances. Clients pay the quote of the durable asset plus their monthly gas bill. More recently, this line of credit was opened for educational programs using a multilateral bank loan (Trochez, 2014; IADB, 2017). Following this business strategy, the public services company of Medellin (EPM) offers credit cards, microfinances and also open credit lines for home improvements and investments such as household expansions and renovations (EPM, 2017). The second strategy, also implemented in Medellin, is "Banco Oportunidades". The program has been implemented since 2013 and is possibly the most comprehensive intervention that provides credit to the poor in the country. It has credit lines for microfinances, educational loans and cooperatives, and has a targeted program for street vendors. The interest rate is usually below market value $(0.91 \%$ per month) and individuals who have been reported as risky-borrowers in credit score databases by formal financial institutions can access small loans equivalent to about a minimum monthly salary (Alcaldía de Medellín, 2017).

Other emerging methods of financial inclusion of the poor are peer-to-peer lending and impact bonds. Peer-to peer lending brings together non-institutional borrowers and lenders. Borrowers upload their business plan on a specialized website and lenders decide under which terms they are willing to provide the requested capital (Mild et al., 2015). In this context, individual investors bear the credit risk instead of financial institutions specialized in risk-management (Serrano-Cinca et al., 2015). As many loans are not secured, only the estimated return of the productive activity can be expected. Currently, the opportunity cost of investment on peer-to-peer platforms is high since the investors' risk is still not fully compensated (Mild et al., 2015).

Impact bonds are an impact investment vehicle. Impact investing refers to investments that deliver measurable social/environmental returns along with financial profits (Bugg-Levine \& Emerson, 2011; Nicholls, 2010; Ormiston et al., 2015). Impact bonds are an outcome-based policy-making strategy in which private investors receive a rate of return if pre-agreed social/environmental outcomes are achieved (Liebman, 2011; Rivera-Acevedo, 2015). At the time of this research, 93 impact bonds are being implemented, including one in Colombia (Social Finance UK, 2017). This instrument shows great potential in the area of poverty alleviation through financial inclusion combining seed capital, savings, skills training, coaching, confidence-building and social support (Instiglio, 2017). 


\section{Assessing the Credit Risk of Street Vendors}

Population data in Colombia -as in many other countries in Latin America- is scarce. In general, cities lack reliable and timely information about the living conditions and socioeconomic status of the inhabitants, as it is not continually collected by local administrations. This is usually due to a lack of funding as well as an absence of evaluation culture which restricts an informed policy-decision making process. The last population census was collected in 2005. Even though the central administration has implemented different population surveys since, these are mostly representative of smaller regions ("departamentos").

Information about banking and access to credit is not available at city level and is not collected systematically by the central government. According to reports by the Colombian financial union association ("ASOBANCARIA"), about 26 million of Colombians have had access to at least one banking service by 2017. Most of those services are referred to saving accounts and only 54\% of those services were used at least once in the past 6 months (El Tiempo, 2017). This information, however, does not disclose the socioeconomic background of the customers and says little about the financial inclusion of the poor.

One effort made by the government to introduce the poor to the regulated banking system was to make mandatory saving accounts for the deposit of money from "Familias en Acción" (FA). FA is one of the largest welfare programs in Colombia. It gives bi-monthly cash transfers to mothers in strata 1 and 2 based on their age and number of children. The precondition of a bank account has been implemented since 2010 and currently, over 2.5 million families are beneficiaries of this program (Prosperidad Social, 2017).

Access to formal financial institutions is expensive. In Colombia, it is necessary to open a bank account when employed in the formal sector. Salary bank accounts require at least a handling fee. The cost of this handling fee is only marginal if receiving a salary deposit once or twice a month. In the informal sector, pay-day jobs such as domestic work, construction or street vending are common and do not have access to salary bank accounts as they cannot guarantee a reliable income. The option of a saving account is given, but it involves a handling fee plus a fee and waiting time for every withdrawal and deposit. In that regard, the day-to-day structure of street vendors increases the opportunity cost of banking as it is a short-term commercial activity that requires a constant cash-flow and instant cash payment since merchandise is usually purchased from wholesalers on a daily basis (Martínez \& Rivera-Acevedo, forthcoming).

In a previous analysis, the authors found that the average monthly income of a street vendor is $20 \%$ higher than the income of an individual in the same socioeconomic strata with more education, and also higher than the income of an average middle class individual in the city (Martínez et al., 2017). But despite their higher income, street vendors are unable to capitalize on their earnings through durable goods like a household. $38 \%$ of individuals in strata 1 and 2 own a house, whereas only $28 \%$ of street vendors report the same asset (ibid). A possible reason explaining the inability of street vendors to capitalize on their earnings and move out of poverty is their high indebtedness rate with payday-loans (Martínez, Rivera-Acevedo, forthcoming). Their major source of credit are illegal moneylenders. This is due to their lack of access to regulated banking services and legal credit because of generally high transaction costs and a high level of information asymmetry.

An information asymmetry is present when one party has more or better information than the other. In terms explained by Akerlof (1970), lenders face adverse selection and moral hazard problems. Adverse selection is present because the lender does not know if the project is good or not (or if the street vendor is capable of selling the products). Moral hazard is present because the lender does not know if after receiving the loan, the borrower will successfully realize the project or if after the project succeeds, the borrower will pay back the loan plus the interest. The best way to reduce information asymmetries is using outside rating firms and guarantees (Akerlof, 1970). However, the poor do not have any collateral and rating firms are too expensive. Therefore, a different approach is needed. 


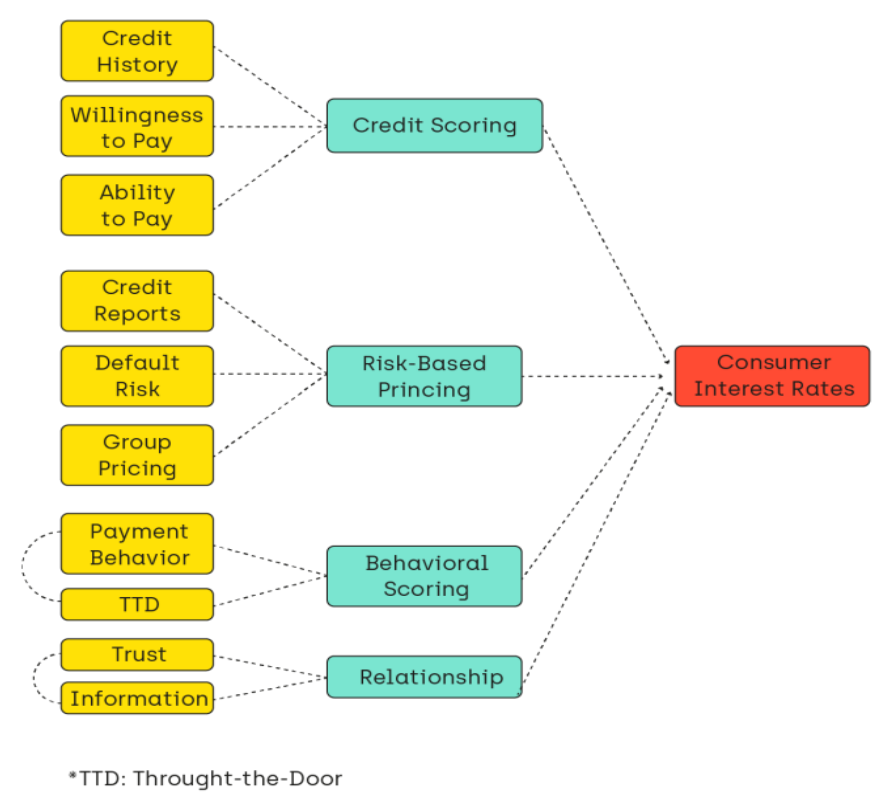

Source: Adapted from (Oh \& Johnston, 2014)

Figure 1. Pricing decision model

Oh \& Johnston (2014) studied the credit card market and proposed a pricing model for managing credit risk. The model consists of four factors that influence the consumer interest rate: Credit scoring, risk-based pricing, behavioral scoring and the relationship between the bank and the borrower. Credit scoring contains information regarding credit history, willingness to pay and ability to pay. Risk- based pricing takes into account credit reports, default risk, and group pricing. Behavioral scoring comprises payment behavior and "through-the-door" (TTD) analysis, which includes factors such as education level and income status. The relationship factor consists of information regarding trust and the reliability of the information provided (see figure 1). This pricing model for credit cards can be adapted to a microloan context by also taking into account that the factors explaining default on peer-to-peer loans are the purpose of loans, annual income, current housing situation, credit history and indebtedness (Serrano-Cinca et al., 2015).

As a result of previous studies by the authors, one of the major hypothesis of this present study is that risk borrowers with a long history of unregulated credit sources (such as payday-loans) pay back their debts and that therefore their repayment capacity is high. However, given the unregulated nature, transactions in the moneylending business are not officially recorded and cannot be taken into account for formal lending purposes, even though this additional information can help build a more accurate profile of a risk borrower.

In order to determine the profile of a risk borrower, a set of 62 questions was created concerning the economic capabilities of the poor (see annex 1). These questions are a tool to reduce information asymmetries between financial organizations and lenders who do not comply with lending standards set by regulated financial institutions. Some of the questions are widely used by national and local governments to target social welfare beneficiaries and identify spending priorities to support the poor. Other questions have been used by regulated financial institutions or the research center POLIS of the University ICESI in Cali. As in other studies by the authors, the questionnaire survey is designed to be taken by pollsters.

The proposed borrower risk profile is divided into five components: i) demographic information; ii) employment and health; iii) household conditions; iv) income and expenses; v) access to banking services and indebtedness (see figure 2).

The section of employment and health accounts for three aspects. First, questions taken from national surveys implemented by the central government collect information about employment and sector (formal or informal). A second set of questions explores the quality of employment, e.g. hours worked, benefits besides salary, employment satisfaction and employment stability. All the questions included in this component have been tested in Cali in extensive population surveys. The results show a high prevalence of informal employment, scarce benefits, and low employment stability within the sample population (POLIS, 2017). Thirdly, this section accounts for the perceived health condition, which is a key proxy of productivity. 
The component household conditions are mostly drawn from national surveys that assess basic needs in households such as sanitation conditions, access to potable water and building structure. These surveys have been widely implemented in Latin America and at the national level. The statistical agency of the country (DANE) has designed and tested composite indicators to determine a household's unmet basic needs (Feres \& Mancero, 2001). This study follows the methodological guidelines implemented by the government to establish the extent of unmet needs amongst risk borrowers.

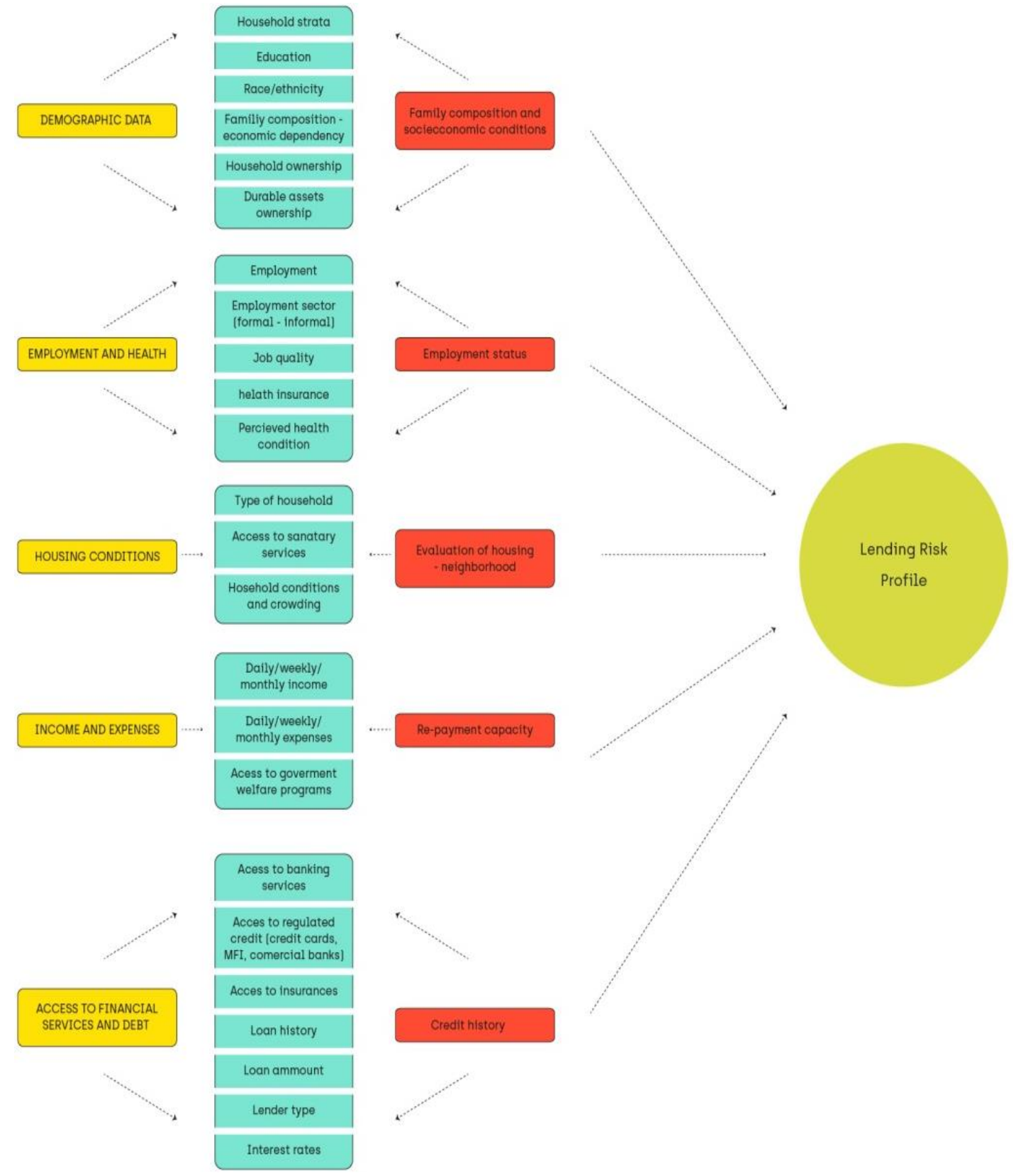

Source: Authors

Figure 2. Credit Risk Assessment for People at the Bottom of the Pyramid

The questions in the income and expenses component are a simplified version of the ones used in official surveys by the government, given the low educational attainment of our target population. This section inquires about access to welfare programs and retirement program contributions. The questions have been tested in previous studies with poor populations such as garbage collectors (Estrada et al., 2017) and street vendors (Martínez et al., 2017). The results of these studies have been used to portray the living conditions of the most impoverished population of Cali. For example, a garbage collector earns less than 7 dollars per day on average, and their entire income is spent on shelter and food for about 4 people (the average family size). 
The section about access to banking services and indebtedness inquires about credit history, type of loaner (moneylender, MFI, bank) and interest rates in current and past loans. All the questions in this section have been tested with street vendors in Cali. The results show that on average, street vendors have a higher monthly income than a worker in the formal sector with greater educational attainment. However, the high indebtedness of street vendors makes it almost impossible to capitalize on the earnings and escape poverty (Martínez \& Rivera-Acevedo, forthcoming).

The information collected through this survey provides the necessary independent variables to analyze the risk of default (dependent variable). Conducting the survey before and after the loan is granted will offer specific insights into the effect of the loan on the quality of life of the borrowers. Continuous monitoring of the variables will establish a lending risk profile of the poor and reduce the information asymmetries that lenders must assess before lending to informal workers. The profile risk that is created with the information collected through this survey is one of the main inputs for implementing programs that promote financial inclusion.

\section{Discussion and Policy Implications}

The informal economy in Colombia is a relevant and interesting research topic. The informality and its consequences in general, as well as the economic activity of street vending in particular, are of high priority for policy-makers.

The internal armed conflict caused the relocation of farmers from rural areas to the cities. The sudden influx of people without the necessary skills to thrive in urban areas segregated them into economic activities in the informal sector. This sector is characterized by unstable working conditions, vulnerability to economic cycles and a lack of access to formal financial institutions. Street vending represents an important part of the informal sector. It is a cash-based day-to-day activity that requires a constant money flow. Without access to formal financial institutions, street vendors turn to illegal moneylenders for the necessary cash to run their business.

Street vendors in Cali have the financial capacity to pay back their debts, but are trapped by moneylenders and payday-loans. They have a higher income than the average working age citizen, especially other individuals classified as poor by national standards who work in the formal sector and have higher levels of education. Nevertheless, they are not able to capitalize on their earnings and remain cataloged as poor (strata 1 and 2) because the interest rates demanded by moneylenders absorb their profits (interests rates can reach up to $20 \%$ interest per month). An alternative to moneylenders are MFIs offering credits at comparatively lower interest rates but the access is limited.

The current policies implemented by the government of Cali to cope with informality and street vending in particular have not shown the desired outcomes. Therefore, the proposed tool aims at reducing information asymmetries to incentivize the financial inclusion of the poor. The borrower risk profile based on the questionnaire survey with five components offers a comprehensive overview of the needs and re-payment capabilities of the poor. However, data collection is expensive. Nevertheless, this task could be carried out by official entities of the city. So far, the different government offices that operate social programs in Cali using public resources do not have a standardized format to characterize the beneficiary population. They often collect irrelevant information. Furthermore, their instruments usually do not draw conclusions about the living conditions of the beneficiaries, and even less about access to credit and indebtedness. The advantages of data collection through government offices are as follows. First, the government can rely on timely standardized information about the living conditions of the poor with access to public social programs. Second, it would provide the opportunity to craft better targeted programs for credit access. Thirdly, it would save the government money because the data collection could be carried out at the same time as the mandatory update of the program participants. This questionnaire, besides providing the basis to determine the socioeconomic profile of the poor, can also become a useful tool for the government for evaluation purposes, incentivizing the practice of data-based policies.

Individual profiles can increase the flexibility in loan disbursement and repayment schedules as well as reduce the overall transaction cost of microloans. Profiles can be categorized in a rating which can be easily accessible to financial institutions, including MFIs and banks. These ratings can also reduce double-dipping and diminish the transaction costs related to loan due diligence, especially for MFIs. As discussed by Mallick (2012), individual profiling can enhance investment productivity, even more so, if loans are combined with skills training, coaching, confidence-building and social support as in the case of impact bonds.

The proposed risk profile can also be used by impact investors. Granting credit access to people at the bottom of the social pyramid can be a profitable business. One of the major challenges of impact investing is to provide measurable social/environmental impact. In this context, the questionnaire gives a clear overview of the quality of life of the borrowers which can be used as a baseline to measure the impact of microcredits on users. Furthermore, a private company could use the questionnaire and develop a rating to sell it to the government, peer-to-peer platforms, banks, and MFIs, similar to traditional credit score databases. In addition, a utility company in Cali could develop a program similar to "Brilla" in which beneficiaries have access to credit as well as savings. 


\section{Conclusions}

This paper presents a comprehensive questionnaire survey that covers five essential components of living conditions, such as financial status including different aspects of indebtedness. It is designed to be taken by trained pollsters, e.g. employees of the local government offices. The target group is the population at the bottom of the social pyramid in Colombia, but could be adapted to other countries in the Global South. The results of the questionnaire can be used as an instrument for credit risk assessment that takes into account the financial activity of an individual in the formal and informal sector. This could facilitate the inclusion of the poor in the regulated banking system, where credits can be obtained at a much smaller interest rate and under secure conditions. In general, the survey can be used as an effective tool for the government to develop outcome-based policies. According to the findings of the survey, the government can implement targeted social programs that reduce poverty and increase the quality of life of the citizens. The outcome of these projects can be measured with the same questionnaire. Since Colombia has a rare practice of data collection, this would foster an evaluation focused culture. A further option to apply the survey can be the impact investing market as a complement to traditional banks or MFIs. The most interesting financial instruments in this sector are impact bonds and peer-to-peer lending, which also comprise aspects like skill training and coaching.

\section{References}

Abhijit Banerjee, B., Duflo, E., Glennerster, R., \& Kinnan, C. (2015). The Miracle of Microfinance? Evidence from a Randomized Evaluation. American Economic Journal: Applied Economics, 7(1), $22-53$. https://doi.org/10.1257/app.20130533

Akerlof, G. A. (1970). The Market for "Lemons": Quality Uncertainty and the Market Mechanism. The Quarterly Journal of Economics, 84(3), 488-500. https://doi.org/10.2307/1879431

Alcaldía de Medellín. (2017). Banco de las Oportunidades. Retrieved October 25, 2017, from https://www.medellin.gov.co/irj/portal/medellin?NavigationTarget=navurl://fb7c2280b719b905fe73341585c5557b

Armendáriz, B., \& Morduch, J. (2010). The Economics of Microfinance (second edi). Cambridge, Mass: The MIT Press.

Ashta, A. (2009). Microcredit Capital Flows and Interest Rates: An Alternative Explanation. Journal of Economic Issues, 43(3), 661-683. https://doi.org/10.2753/JEI0021-3624430305

Banco de la República (2013). Informe de Coyuntura económica regional. Banco de la República, Bogotá, DC.

Braverman, A., \& Guasch, J. L. (1989). Rural credit in developing countries (Policy No. WDP-219). New York, N.Y: World Bank.

Bugg-Levine, A., \& Emerson, J. (2011). Impact investing: Transforming how we make money while making a difference. Innovations, 6(3), 9-18.

Cali en Cifras. (2017). Oficina de Planeación Municipal. http://www.cali.gov.co/publicaciones/107143/cali_en_cifras_planeacion/Accessed October 10, 2017.

Cerrutti, M., \& Bertoncello, R. (2003). Urbanization and Internal Migration Patterns in Latin America, 4-7. Retrieved from http://citeseerx.ist.psu.edu/viewdoc/download?doi=10.1.1.598.7139\&rep=rep1\&type=pdf

Chen, M. A. (2005). Rethinking the Informal Economy: Linkages with the Formal Economy and the Formal Regulatory Environment. Retrieved from http://www.un.org/esa/desa/

Chen, M. A. (2012). The Informal Economy: Definitions, Theories and Policies. Retrieved from www.wiego.org

Christiaensen, L., \& Todo, Y. (2014). Poverty reduction during the rural-urban transformation-the role of the missing middle. World Development, 63, 43-58.

Dalla Pellegrina, L. (2011). Microfinance and Investment: A Comparison with Bank and Informal Lending. World Development, 39, 882-897. https://doi.org/10.1016/j.worlddev.2011.03.002

DANE (2013). Pobreza en Colombia. Comunicado de prensa. https://www.dane.gov.co/files/investigaciones/condiciones_vida/pobreza/cp_pobreza_20122.pdf. Accessed October 9, 2017.

DANE (2015a). Estadísticas por tema. Demografía y población. http://www.dane.gov.co/index.php/ estadisticas-por-tema/demografia-y-poblacion. Accessed October 9, 2017.

DANE (2015b). Medición del Empleo Informal y Seguridad Social. Retrieved September 20, 2015, from http://www.dane.gov.co/files/investigaciones/boletines/ech/ech/bol_eje_informalidad_may_jul_15.pdf

DNP. (1997). La estratificación socioeconómica Avance y Retos. Documento CONPES 2904. Bogotá. Retrieved from https://colaboracion.dnp.gov.co/CDT/CONPES/Económicos/2904.pdf 
Donovan, M. G. (2008). Informal Cities and the Contestation of Public Space: The Case of Bogotá's Street Vendors, 1988-2003. Urban Studies, 45(1), 29-51. https://doi.org/10.1177/0042098007085100

El Tiempo (2017). Cerca de 7 millones de habitantes están sin bancarizar. http://www.eltiempo.com/economia/finanzas-personales/nivel-de-bancarizacion-en-colombia-2017-107896 Accessed October 10, 2017.

EPM. (2017). Crédito Somos. Retrieved October 25, 2017, from https://www.somosgrupoepm.com/descubre/credito

Estrada, D., Martínez, L., \& Zuluaga, B. (2017). Detrás de la carreta: ¿Cómo viven los recuperadores ambientales de Cali?

Feres, J. C., \& Mancero, X. (2001). El método de las necesidades básicas insatisfechas (NBI) y sus aplicaciones en América Latina. Retrieved from http://repositorio.cepal.org/bitstream/handle/11362/4784/S0102117_es.pdf;jsessionid=38D779356F369DE275871 6931616DE6E? sequence $=1$

Gaspirini, L. and Tornarolli, L., (2007). Labor informality in Latin America and the Caribbean: Patterns and trends from household survey microdata, CEDLAS working Paper ${ }^{\circ}$ 46, La plata, Centro de Estudios Distributivos Laborales y sociales.

Guha, B., \& Chowdhury, P. R. (2013). Micro-finance competition: Motivated micro-lenders, double-dipping and default. Journal of Development Economics, 105, 86-102. https://doi.org/10.1016/j.jdeveco.2013.07.006

ILO. (2014). Transition to formality in Latin America and the Caribbean. Lima: ILO, Regional Office for Latin America and the Caribbean. Retrieved from http://www.ilo.org/wcmsp5/groups/public/---americas/---ro-lima/documents/publication/wcms_314469.pdf

ILO-FORLAC. (2014). Oficina Regional para América Latina y el Caribe. Retrieved from http://www.ilo.org/wcmsp5/groups/public/---americas/---ro-lima/documents/publication/wcms_245615.pdf

Instiglio (2017). Extreme Poverty Burkina

Inter-American Development Bank -IADB. (2017). Proyectos - CO-L1089: Promigas: Programa de Financiación No Bancaria Brilla. Retrieved October 25, 2017, from http://www.iadb.org/es/proyectos/project-information-page,1303.html?id=CO-L1089

Kar, A. K., \& Swain, R. B. (2014). Interest Rates and Financial Performance of Microfinance Institutions: Recent Global Evidence. European Journal of Development Research, 26(1), 87-106. https://doi.org/10.1057/ejdr.2013.33

Liebman, J. B. (2011). Testing Pay-for-Success Bonds. Public Manager, 40(3), 66-68.

Mallick, D. (2012). Microfinance and Moneylender Interest Rate: Evidence from Bangladesh. World Development, 40(6), 1181-1189. https://doi.org/10.1016/j.worlddev.2011.12.011

Martínez, L., \& Rivera- Acevedo, J. D. (forthcoming). Debt Portfolios of the Poor: The Case of Street Vendors in Cali, Colombia. Under revision.

Martínez, L., \& Estrada, D. (2017). Street vending and informal economy: Survey data from Cali, Colombia. Data in Brief, 14, 132-137. https://doi.org/10.1016/j.dib.2017.06.047

Martínez, L., Short, J. R., \& Estrada, D. (2017). The urban informal economy: Street vendors in Cali, Colombia. Cities, 66, 34-43. https://doi.org/10.1016/j.cities.2017.03.010

Martínez, L., \& Short, J. R. (2016). The Informal Economy of Cities in The South: The Case of Cali, Colombia. International Journal of Sustainable Development and Planning, 12(4), 637-643. https://doi.org/10.2495/SDP-V12-N4-637-643

Mild, A., Waitz, M., \& Woeckl, J. (2015). How low can you go? - Overcoming the inability of lenders to set proper interest rates on unsecured peer-to-peer lending markets. Journal of Business Research, 68(6), 1291-1305.

Montgomery, H., \& Weiss, J. (2005). Great Expectations: Microfinance and Poverty Reduction in Asia and Latin America. Retrieved from www.adbi.org

Nicholls, A. (2010). The Institutionalization of Social Investment: The Interplay of Investment Logics and Investor Rationalities. Journal of Social Entrepreneurship, 1(1), 70-100. https://doi.org/10.1080/19420671003701257

Oh, J.-H., \& Johnston, W. J. (2014). Credit lender-borrower relationship in the credit card market - Implications for credit risk management strategy and relationship marketing. International Business Review, 23(6), 1086-1095. 
https://doi.org/10.1016/j.ibusrev.2014.06.010

Ormiston, J., Charlton, K., Donald, M. S., \& Seymour, R. G. (2015). Overcoming the Challenges of Impact Investing: Insights from Leading Investors. Journal of Social Entrepreneurship, 6(3), 352-378. https://doi.org/10.1080/19420676.2015.1049285

POLIS - Observatorio de Políticas Públicas (2017). Life satisfaction: Measurement and its implications for public policy formulation. POLIS policy brief 17:5-21. Universidad Icesi, Cali-Colombia.

Poveda, A. C. (2011). Economic Development, Inequality and Poverty: An Analysis of Urban Violence in Colombia. Oxford Development Studies, 39(4), 453-468.

Prosperidad Social. (2017). Retrieved December 18, 2017, from http://www.dps.gov.co/Paginas/Inicio.aspx

Quinones, B., \& Remenyi, J. (2014). Microfinance and poverty alleviation: Case studies from Asia and the Pacific. Routledge.

Rivera-Acevedo, J. D. (2015). Market-based Solutions for Social Challenges: A Collaborative Policy Making Strategy. https://doi.org/10.13140/RG.2.1.2960.5203

Roberts, P. W. (2013). The Profit Orientation of Microfinance Institutions and Effective Interest Rates. World Development, 41, 120-131. https://doi.org/10.1016/j.worlddev.2012.05.022

Serrano-Cinca, C., Gutierrez-Nieto, B., \& Lopez-Palacios, L. (2015). Determinants of Default in P2P Lending. Plos One, 10(10), e0139427. https://doi.org/10.1371/journal.pone.0139427

Serrano-Cinca, C., \& Gutierrez-Nieto, B. (2014). Microfinance, the long tail and mission drift. International Business Review, Vol 23 (1), pp 181-194

Social Finance UK. (2017). Impact Bond Database.

Superintendencia Financiera de Colombia. (2017). Certificación del Interés Bancario Corriente para las modalidades de Crédito de Consumo y Ordinario, Microcrédito y Consumo de Bajo Monto.

Swain, R. B. (2012). The Microfinance Impact. Routledge.

Trochez, G. (2014). Promigas aspira a que su programa Brilla acabe el año con 1,2 millones de personas beneficiadas. La República. Retrieved October 25, 2017, from https://www.larepublica.co/responsabilidad-social/promigas-aspira-a-que-su-programa-brilla-acabe-el-ano-con-12millones-de-personas-beneficiadas-2143416 
Annex 1. Survey - Credit Risk Assessment for People at the Bottom of the Social Pyramid

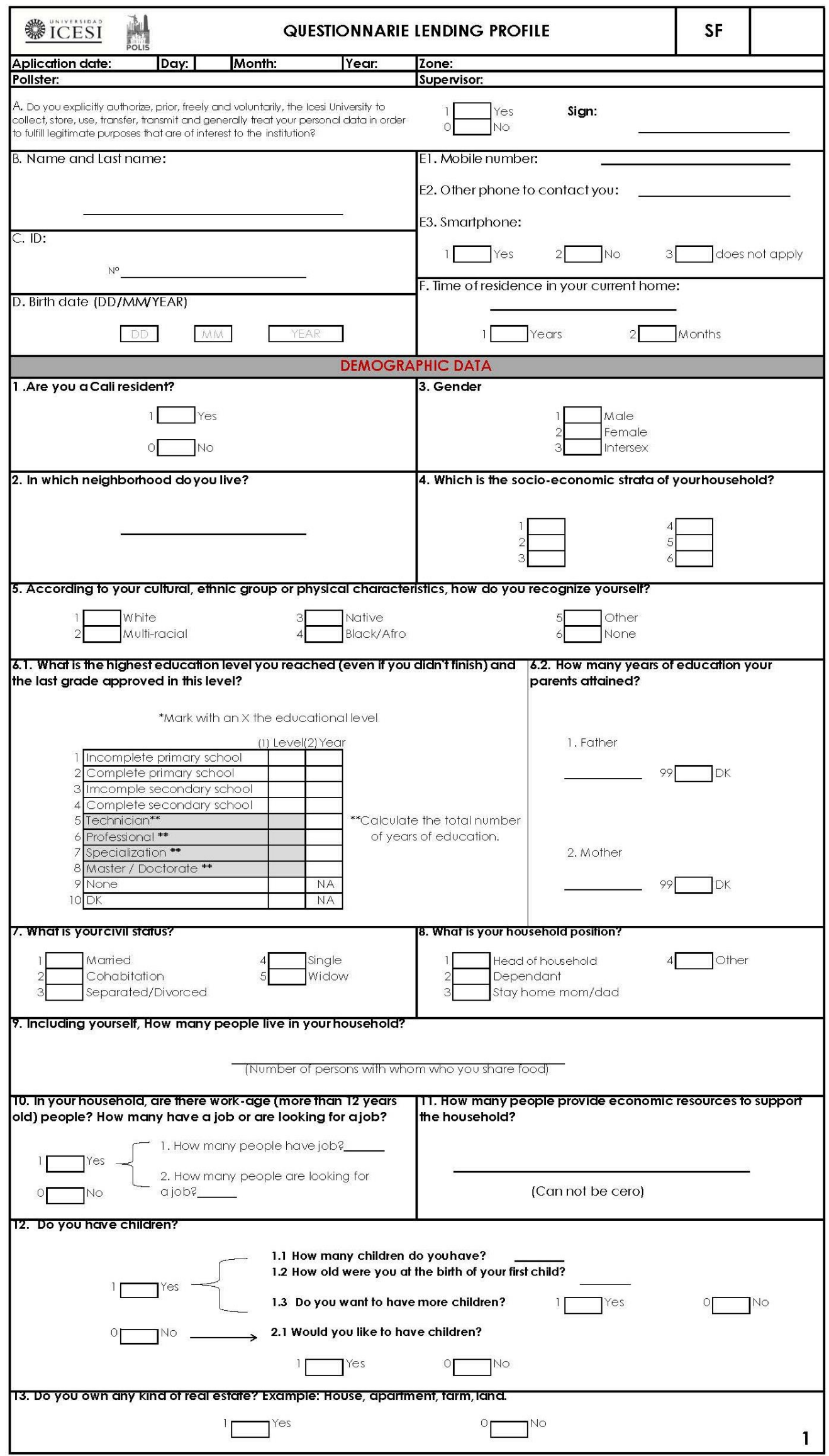




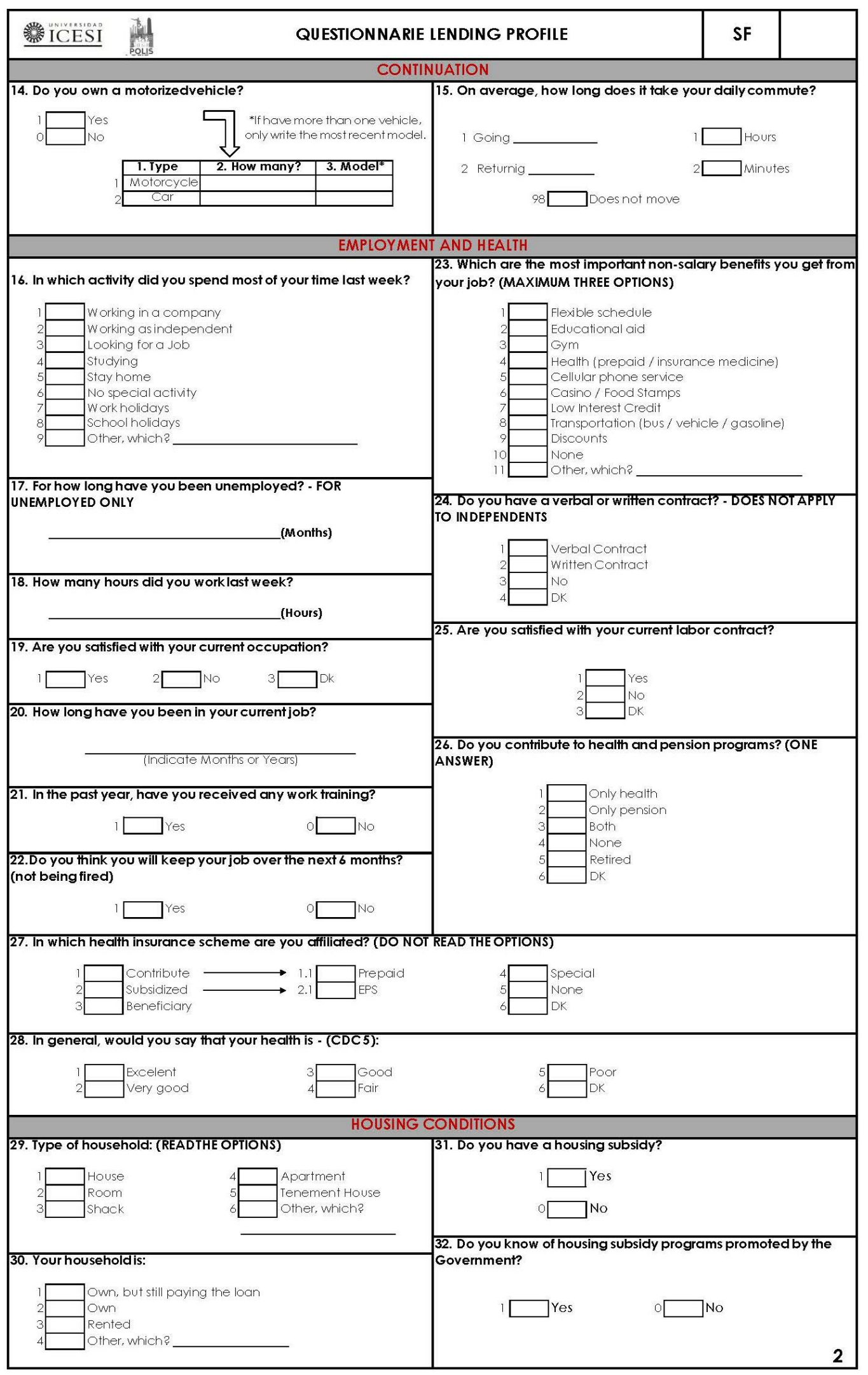




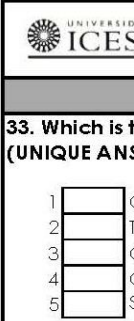

34. Which is the prevailing material of the walls in your house? (UNIQUE ANSWER)

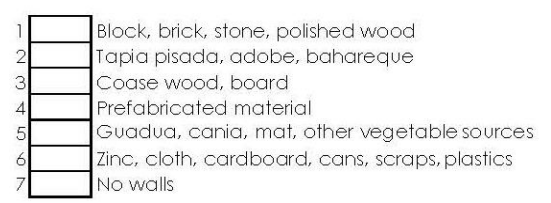

35. How many rooms does your household have? (do not include bathrooms and kitchen)

(Number)

36. How many rooms are used to sleep? (Number)

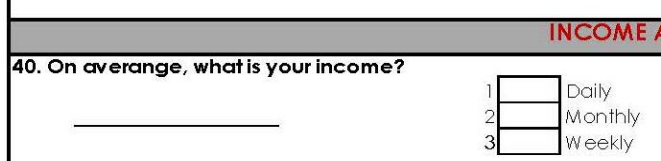

41. Including housing, food, services, and others, the expenses at your home are approximately:

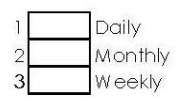

42. Over the last twelve months, have any member of your household received subsidies from the government either in cash or in kind?

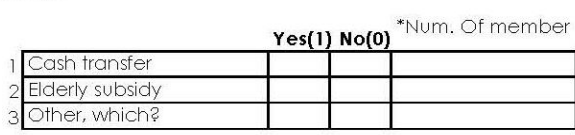

\section{ACCESS TO FINAINCIAL SERVICES AND DEBT}

\begin{tabular}{l|l} 
44. Do you have an active savings account with abank or & 48. How was if Paid? (MULTIPLE ANSWER)
\end{tabular} financial institution?

$$
1 \square \text { Yes }
$$

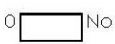

45. Do you have a crealf card?

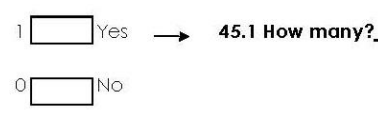

46. Do you have cinficulfies paylng you debts?

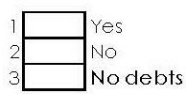

47. Which is the maln asset al your home?

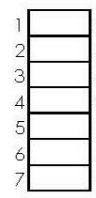

\section{car}

Motorcycle

Owning a hosehold

computer

Home appliances (fridge / washing machine / etc

None
other, which?

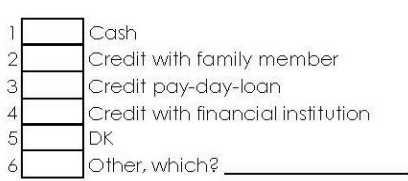

49. Do you pay for any kindof insurance? (read options) MULTIPLE CHOICE

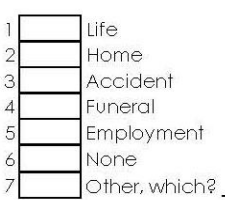

50. Do you have anyone to lend you money?

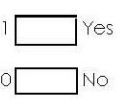

SF

ave?

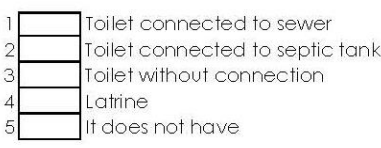

38. Your hause have access to:

\begin{tabular}{|c|c|c|}
\hline & Yes(1) & ) $\mathrm{No}(\mathrm{C}$ \\
\hline Aqueduct & & \\
\hline Energy & & \\
\hline 3 Gas & & \\
\hline$4 \longdiv { \text { Sewerage } }$ & & \\
\hline 5 Garbage collection & & \\
\hline
\end{tabular}

39. The water to prepare food, are obtained mainly from: (UNIQUE

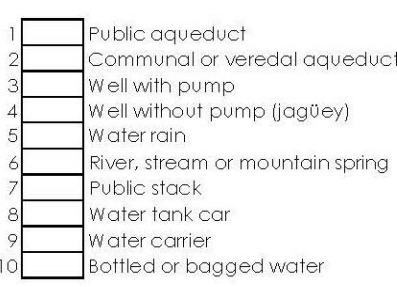

43. Which measurements have you taken to secure a good life when you get older? (MULTIP LE ANSWER)

1 Expectsupport from his/her children

$2 \square$ save money for the future

$3 \square^{\text {Try to organize a business / osset that guarantees an income }}$

4 Listed in a pension fund

5 He/she hopes that someday he/she'll get the money to save $6 \square$ Nothing

$7 \square^{\text {Other, which? }}$ 


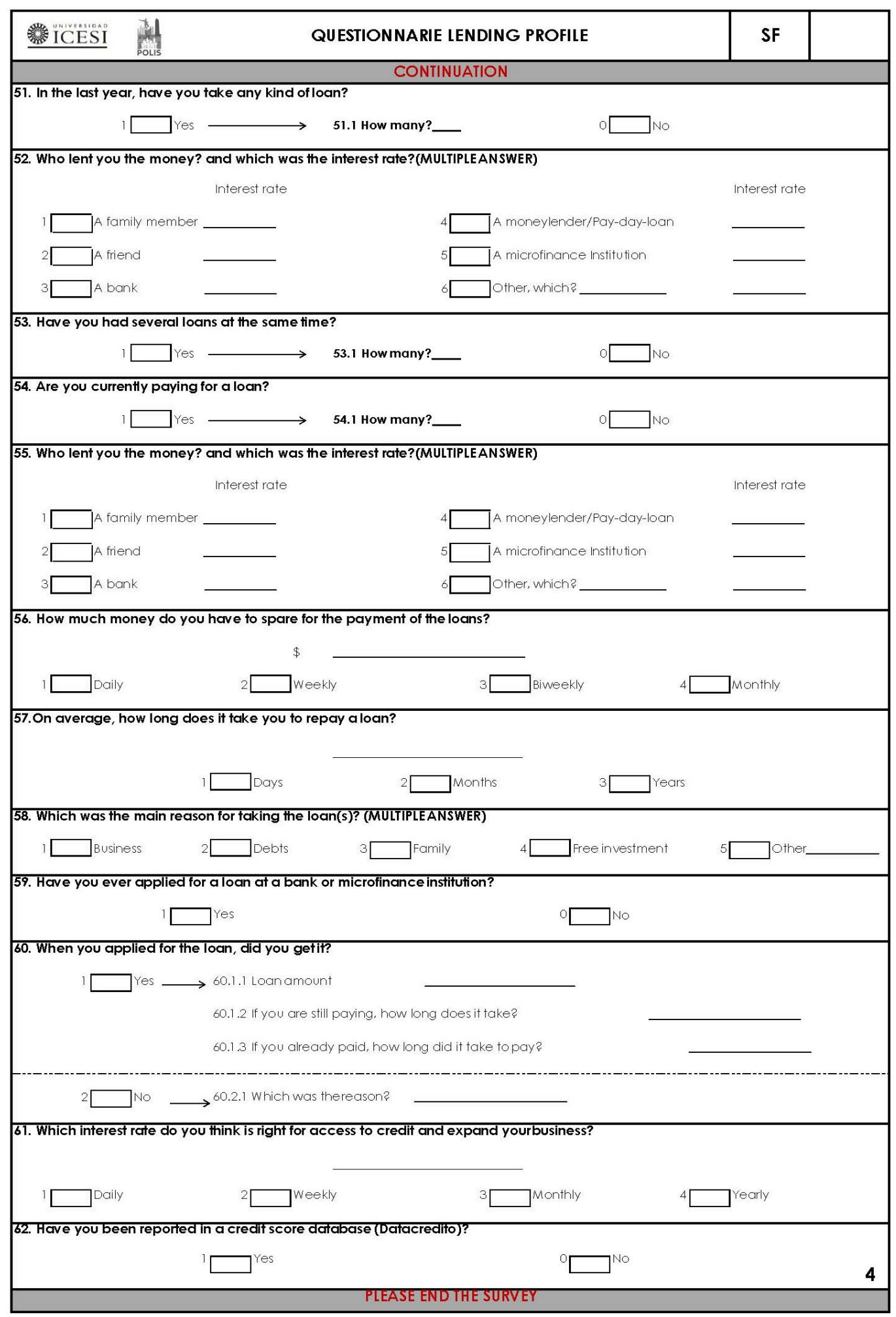

\section{Copyrights}

Copyright for this article is retained by the author(s), with first publication rights granted to the journal.

This is an open-access article distributed under the terms and conditions of the Creative Commons Attribution license (http://creativecommons.org/licenses/by/4.0/). 